\title{
Andreprevotia chitinilytica gen. nov., sp. nov., isolated from forest soil from Halla Mountain, Jeju Island, Korea
}

Correspondence

Soon-Wo Kwon

swkwon@rda.go.kr

\author{
Hang-Yeon Weon, ${ }^{1}$ Byung-Yong Kim, ${ }^{2}$ Seung-Hee Yoo, ${ }^{2}$ Jae-Ho Joa, ${ }^{3}$ \\ Soon-Wo Kwon ${ }^{2}$ and Wan-Gyu Kim ${ }^{1}$
}

\author{
${ }^{1}$ Applied Microbiology Division, National Institute of Agricultural Science and Technology, \\ Rural Development Administration, Suwon 441-707, Republic of Korea \\ ${ }^{2}$ Korean Agricultural Culture Collection (KACC), Microbial Genetics Division, National Institute \\ of Agricultural Biotechnology, Rural Development Administration, Suwon 441-707, \\ Republic of Korea \\ ${ }^{3}$ National Institute of Subtropical Agriculture, Rural Development Administration, Jeju 690-150, \\ Republic of Korea
}

\begin{abstract}
A motile, Gram-negative, rod-shaped bacterium, designated strain $\mathrm{JS} 11-7^{\top}$, was isolated from forest soil from Halla Mountain, Jeju Island, Korea. It grew optimally at $28^{\circ} \mathrm{C}, \mathrm{pH} 6-7$ and in the presence of $0-2 \%(\mathrm{w} / \mathrm{v}) \mathrm{NaCl}$. Phylogenetic analyses based on 16S rRNA gene sequences showed that strain $\mathrm{JS} 11-7^{\top}$ belongs to the family Neisseriaceae, with Silvimonas terrae as its closest relative (95.0\% similarity). It contained $\mathrm{Q}-8$ as the predominant quinone and summed feature 3 (comprising iso- $\mathrm{C}_{15: 0} 2-\mathrm{OH}$ and/or $\mathrm{C}_{16: 1} \omega 6 c$ ), $\mathrm{C}_{16: 0}$ and $\mathrm{C}_{18: 1} \omega 7 c$ as the major fatty acids. The DNA G +C content was $62 \mathrm{~mol} \%$. On the basis of phenotypic and genotypic characteristics and the results of $16 \mathrm{~S}$ rRNA gene sequence analysis, strain $\mathrm{JS} 11-7^{\top}$ represents a novel genus and species, for which the name Andreprevotia chitinilytica gen. nov., sp. nov. is proposed. The type species is Andreprevotia chitinilytica and the type strain is JS11- $7^{\top}$ (=KACC $11608^{\top}=$ DSM $18519^{\top}$ ).
\end{abstract}

The soil of Jeju Island, located in southern Korea, is largely derived from ash from volcanic eruptions. Consequently, the microbial habitats of these soil environments are thought to differ from those of the Korea mainland. In the course of a study on the microbial community in forest soil from Jeju, we collected a soil sample from Halla Mountain on Jeju Island, Korea.

A $1 \mathrm{~g}$ soil sample was suspended in $9 \mathrm{ml} 0.85 \% \mathrm{NaCl}$ (w/v) and mixed in a shaker for $30 \mathrm{~min}$. After serial dilution, the aliquots of the serial diluents were spread on R2A agar plates (Reasoner \& Geldreich, 1985) and incubated at $28^{\circ} \mathrm{C}$ for 5 days. Isolate JS1 $1-7^{\mathrm{T}}$ was cultured routinely and maintained on R2A agar at $28{ }^{\circ} \mathrm{C}$. It also grew on nutrient agar (Difco) and tryptic soy agar (TSA; Difco). However, no growth was observed on MacConkey agar (Difco).

The genomic DNA was isolated by using the method of Ausubel et al. (1987) except that the lysates were extracted

The GenBank/EMBL/DDBJ accession number for the 16S rRNA gene sequence of strain JS11-7 $7^{\top}$ is DQ836355.

A transmission electron micrograph of strain $\mathrm{JS} 11-7^{\top}$ and a list of the cellular fatty acids present in $\mathrm{JS} 11-7^{\top}$ and related species are available as supplementary data with the online version of this paper. twice with chloroform to remove residual phenol. The $16 \mathrm{~S}$ RNA gene sequence of strain JS1 $1-7^{T}$ was analysed as described by Kwon et al. (2003). The sequences obtained were compared with reference $16 \mathrm{~S}$ rRNA gene sequences available from the GenBank and EMBL databases. A phylogenetic analysis was carried out using the MEGA3 program (Kumar et al., 2004), after multiple alignments of the data had been obtained using CLUSTAL W (Thompson et al., 1994). Phylogenetic dendrograms were constructed using the neighbour-joining (Saitou \& Nei, 1987) and maximumparsimony (Fitch, 1971) methods, with bootstrap values based on 1000 replications. Analyses based on the 16S rRNA gene sequence (1407 bases of strain $\mathrm{JS} 11-7^{\mathrm{T}}$ ) revealed that strain JS1 $1-7^{\mathrm{T}}$ had the highest level of sequence similarity $(95.0 \%)$ with respect to Silvimonas terrae KM- $45^{\mathrm{T}}$ (accession no. AB194302). On the other hand, all other species with validly published names showed low levels of sequence similarity $(<92.2 \%)$. These sequence similarity data are consistent with the phylogenetic dendrogram (Fig. 1), in which strain JS1 $1-7^{\mathrm{T}}$ clusters with $S$. terrae KM- $45^{\mathrm{T}}$ (Yang et al., 2005) with $100 \%$ bootstrap support. The genera Formivibrio citricus (Tanaka et al., 1991), Chitinibacter tainanensis (Chern et al., 2004) and Iodobacter fluviatilis (Logan, 1989) are also shown to be closely related to strain 


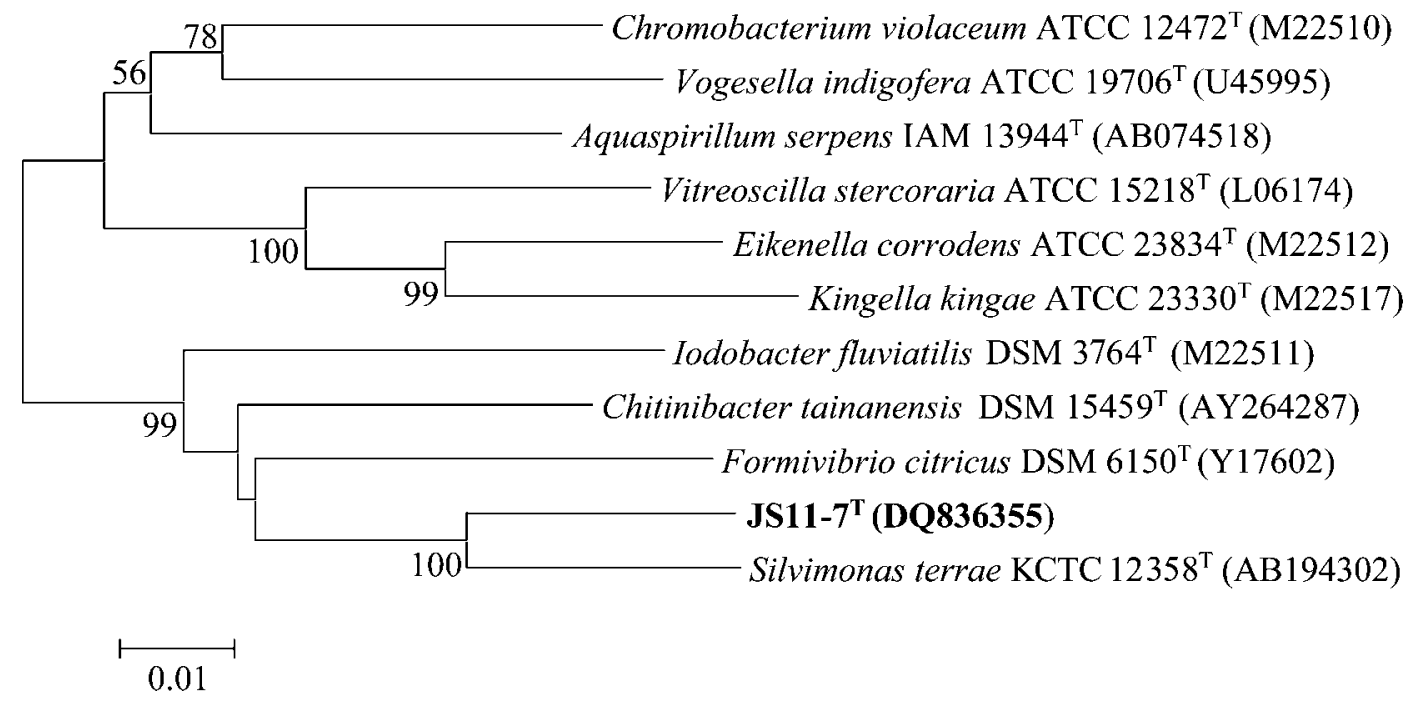

Fig. 1. Neighbour-joining phylogenetic tree, derived from $16 \mathrm{~S}$ rRNA gene sequences, showing the position of strain JS11-7 ${ }^{\top}$. Numbers at the nodes indicate levels of bootstrap support (based on 1000 resampled datasets). Bootstrap values below $50 \%$ are not shown. Bar, 0.01 substitutions per site.

JS11-7 ${ }^{\mathrm{T}}$. The monophyletic clade that includes these five taxa was also supported by the maximum-parsimony analysis.

The G+C content of the DNA of strain JS11-7 ${ }^{\mathrm{T}}$ was determined as described by Mesbah et al. (1989), using a reversed-phase column (Supelcosil LC-18-S; Supelco), and was found to be $62 \mathrm{~mol} \%$.

For the chemotaxonomic analysis, cells were grown for $48 \mathrm{~h}$ growth at $28{ }^{\circ} \mathrm{C}$ on TSA medium. A fatty acid methyl ester analysis was performed according to the standard protocol of the Microbial Identification System (MIDI; Microbial ID). Isoprenoid quinones were analysed by HPLC as described previously (Groth et al., 1996). Strain JS11-7 contained summed feature 3 (iso- $\mathrm{C}_{15: 0} 2-\mathrm{OH}$ and/or $\left.\mathrm{C}_{16: 1} \omega 7 c ; 39.5 \%\right), \mathrm{C}_{16: 0}(31.1 \%)$ and $\mathrm{C}_{18: 1} \omega 7 c(15.8 \%)$ as the major fatty acids (see supplementary Table S1, available with the online version of this paper). The predominant isoprenoid quinone was Q-8.

To investigate the basic physiological and biochemical characteristics, we used the methods of Smibert \& Krieg (1994) for the following tests: the Gram reaction, oxidase and catalase reactions, the deamination of phenylalanine, the Voges-Proskauer test and the hydrolysis of CMcellulose, casein, chitin, DNA, pectin, starch, tyrosine and Tween 80 . The temperature range $\left(5-45^{\circ} \mathrm{C}\right.$, using increments of $\left.5{ }^{\circ} \mathrm{C}\right), \mathrm{pH}$ range $(4-10$, using increments of $1 \mathrm{pH}$ unit) and $\mathrm{NaCl}$ requirement $(0,1,2,3$ and $5 \% \mathrm{NaCl}$, $\mathrm{w} / \mathrm{v})$ were determined using R2A medium. For other classical and phenotypic tests, API 20NE, API ID 32GN and API ZYM test kits were also used according to the recommendations of the manufacturer (bioMérieux). The
API ZYM tests were read after $4 \mathrm{~h}$ incubation at $37^{\circ} \mathrm{C}$; the other API tests were read after $48 \mathrm{~h}$ at $28^{\circ} \mathrm{C}$. Cell morphology was observed by using transmission electron microscopy and phase-contrast microscopy (Axio; Zeiss). For transmission electron microscopy, cells were grown on TSA and suspended in physiological saline solution. A small drop of suspension was placed on a carbon-coated copper grid and the cells were negatively stained with $0.5 \%$ uranyl acetate for observation under the electron microscope (model 912AB; LEO).

The cells of strain JS11-7 ${ }^{\mathrm{T}}$ were straight rods, $0.7-0.9 \mu \mathrm{m}$ in diameter and $2.0-3.0 \mu \mathrm{m}$ in length (see supplementary Fig. S1, available with the online version of this paper). The phenotypic properties of $\mathrm{JS} 11-7^{\mathrm{T}}$ are listed in Table 1 and in the genus and species descriptions.

Strain JS11-7 ${ }^{\mathrm{T}}$ was clearly different from its close neighbours, S. terrae, F. citricus, C. tainanensis and I. fluviatilis, as determined by comparative analyses of $16 \mathrm{~S}$ rRNA gene sequences. $F$. citricus could be easily differentiated from strain JS1 $1-7^{\mathrm{T}}$ and other closely related genera in that it was strictly anaerobic, had the ability to hydrolyse chitin, and contained a relatively large amount $(9.5 \%)$ of $\mathrm{C}_{16: 0} 3-\mathrm{OH}$ (Tanaka et al., 1991; Chern et al., 2004). Strain JS11-7 ${ }^{\mathrm{T}}$ differs from $S$. terrae, the closest phylogenetic relative, in terms of several phenotypic properties (the former is unable to grow anaerobically, to reduce nitrate, to hydrolyse aesculin and to grow at $40^{\circ} \mathrm{C}$, but is able to hydrolyse gelatin) and in terms of fatty acid composition [the former lacks $\mathrm{C}_{19: 0} \omega 8 c$ cyclo and summed feature $2\left(\mathrm{C}_{14: 0} 3-\mathrm{OH}\right.$ and/ or iso- $\mathrm{C}_{16: 1} \mathrm{I}$ ), contains small amounts of $\mathrm{C}_{14: 0}$ and $\mathrm{C}_{17: 0}$ cyclo, and a large amount of summed feature 3] (Tables 1 and $\mathrm{S} 1$ ). 
Table 1. Differential characteristics for JS11-7 ${ }^{\top}$ with respect to its closest phylogenetic neighbours

Strains: 1, JS11-7 ${ }^{\mathrm{T}}$; 2, S. terrae KCTC $12358^{\mathrm{T}}$ (Yang et al., 2005; this study); 3, C. tainanensis DSM $15459^{\mathrm{T}}$ (Chern et al., 2004; this study); 4, I. fluviatilis DSM $3764^{\mathrm{T}}$ (Logan, 1989; this study). All of the strains are negative for indole production, arginine dihydrolase and urease. All assimilate D-glucose, $\mathrm{N}$-acetylglucosamine, potassium gluconate and D-ribose. None of the strains assimilates capric acid, adipic acid, malic acid, trisodium citrate, phenylacetic acid, inositol, itaconic acid, suberic acid, sodium malonate, lactic acid, L-alanine, potassium 5-ketogluconate, 3-hydroxybenzoic acid, D-melibiose, D-sorbitol, propionic acid, valeric acid, L-histidine, potassium 2-ketogluconate or 4-hydroxybenzoic acid. All are positive for esterase (C4), leucine arylamidase, acid phosphatase, naphthol-ASBI-phosphohydrolase and $N$-acetyl- $\beta$-glucosaminidase. All are negative for lipase (C14), valine arylamidase, cystine arylamidase, trypsin, $\alpha$-chymotrypsin, $\alpha$-galactosidase, $\beta$-glucuronidase, $\alpha$-mannosidase and $\alpha$-fucosidase. + , Positive; $(+)$, weakly positive; - , negative.

\begin{tabular}{|c|c|c|c|c|}
\hline Characteristic & 1 & 2 & 3 & 4 \\
\hline Anaerobic growth & - & $+^{*}$ & $-\dagger$ & $+\ddagger$ \\
\hline Growth at $40^{\circ} \mathrm{C}$ & - & $+^{*}$ & $+\dagger$ & $-\ddagger$ \\
\hline Nitrate reduction & - & + & - & + \\
\hline Glucose fermentation & + & + & - & - \\
\hline Aesculin hydrolysis & - & + & - & - \\
\hline Gelatin hydrolysis & + & - & - & + \\
\hline \multicolumn{5}{|l|}{ Assimilation of: } \\
\hline L-Arabinose & + & + & - & - \\
\hline D-Mannose & $(+)$ & + & - & + \\
\hline D-Mannitol & + & + & - & - \\
\hline D-Maltose & + & + & - & + \\
\hline L-Rhamnose & + & + & - & - \\
\hline D-Sucrose & - & + & - & - \\
\hline Sodium acetate & $(+)$ & $(+)$ & - & + \\
\hline Glycogen & + & $(+)$ & - & $(+)$ \\
\hline L-Serine & - & - & + & + \\
\hline Salicin & - & + & - & - \\
\hline L-Fucose & - & + & - & - \\
\hline 3-Hydroxybutyric acid & + & $(+)$ & - & $(+)$ \\
\hline L-Proline & $(+)$ & $(+)$ & - & + \\
\hline \multicolumn{5}{|l|}{ Enzyme activities: } \\
\hline$\beta$-Galactosidase & + & + & - & - \\
\hline Alkaline phosphatase & + & + & - & + \\
\hline Esterase lipase (C8) & - & + & - & + \\
\hline$\alpha$-Glucosidase & + & + & - & + \\
\hline$\beta$-Glucosidase & - & + & - & - \\
\hline DNA G $+\mathrm{C}$ content $(\mathrm{mol} \%)$ & 62 & $58^{\star}$ & $56 \dagger$ & $50-52 \ddagger$ \\
\hline
\end{tabular}

${ }^{\star}$ Data from Yang et al. (2005).

$\dagger$ Data from Chern et al. (2004).

$\ddagger$ Data from Logan (1989).

On the basis of the results of the polyphasic analysis, strain JS1 $1-7^{\mathrm{T}}$ represents a novel genus and species, for which the name Andreprevotia chitinilytica gen. nov., sp. nov. is proposed.

\section{Description of Andreprevotia gen. nov.}

Andreprevotia (An.dre.pre.vo.ti'a. N.L. fem. n. Andreprevotia named after André Romain Prévot, the French microbiologist who first named the family Neisseriaceae).

Colonies are ivory-coloured, round and convex with clear margins on R2A medium. Cells are strictly aerobic, Gramnegative, motile with single polar or subpolar flagella and rod-shaped $(0.7-0.9 \times 2.0-3.0 \mu \mathrm{m})$. Positive for oxidase activity, catalase activity and glucose fermentation. Negative for nitrate reduction, Voges-Proskauer reaction and phenylalanine deamination. Major isoprenoid quinone is Q-8. Fatty acids mainly comprise summed feature 3 (iso$\mathrm{C}_{15: 0} 2-\mathrm{OH}$ and/or $\left.\mathrm{C}_{16: 1} \omega 7 c\right), \mathrm{C}_{16: 0}$ and $\mathrm{C}_{18: 1} \omega 7 c$. The DNA $\mathrm{G}+\mathrm{C}$ content of the type strain of the type species is 62 mol\%. 16S rRNA gene sequence analysis places Andreprevotia in the family Neisseriaceae. The type species is Andreprevotia chitinilytica.

\section{Description of Andreprevotia chitinilytica sp. nov.}

Andreprevotia chitinilytica (chi.ti.ni.ly'ti.ca. N.L. n. chitinum chitin; N.L. adj. lyticus dissolving; N.L. fem. adj. chitinilytica chitin-dissolving).

Growth is observed at $5-35^{\circ} \mathrm{C}$ (optimum, $28^{\circ} \mathrm{C}$ ), at pH 5.0 8.0 (optimum, $\mathrm{pH}$ 6.0-7.0) and in medium containing 0-2\% (w/v) NaCl. Degrades Tween 80. Does not degrade aesculin, casein, pectin or tyrosine. According to the API 20NE and API ID 32GN test strips, assimilates D-glucose, L-arabinose, D-mannitol, $N$-acetylglucosamine, D-maltose, potassium gluconate, L-rhamnose, D-ribose, glycogen and 3-hydroxybutyric acid. Shows weak assimilation of D-mannose, sodium acetate and L-proline. Does not assimilate capric acid, adipic acid, malic acid, trisodium citrate, phenylacetic acid, inositol, D-sucrose, itaconic acid, suberic acid, sodium malonate, lactic acid, L-alanine, potassium 5-ketogluconate, 3-hydroxybenzoic acid, L-serine, salicin, D-melibiose, L-fucose, D-sorbitol, propionic acid, valeric acid, L-histidine, potassium 2-ketogluconate or 4-hydroxybenzoic acid. With the API ZYM test strips, positive results are obtained for alkaline phosphatase, esterase (C4), leucine arylamidase, acid phosphatase, naphthol-AS-BI-phosphohydrolase, $\alpha$-glucosidase and $N$-acetyl- $\beta$-glucosaminidase. Negative for esterase lipase (C8), lipase (C14), valine arylamidase, cystine arylamidase, trypsin, $\alpha$-chymotrypsin, $\alpha$-galactosidase, $\beta$-glucuronidase, $\beta$-glucosidase, $\alpha$-mannosidase and $\alpha$-fucosidase.

The type strain, JS11-7 $7^{\mathrm{T}}\left(=\right.$ KACC $\left.11608^{\mathrm{T}}=\mathrm{DSM} 18519^{\mathrm{T}}\right)$, was isolated from forest soil from Halla Mountain, Jeju Island, Republic of Korea.

\section{Acknowledgements}

This work was supported by a grant (no. 06-4-11-19-1) of National Institute of Agricultural Biotechnology, Rural Development Administration of Republic of Korea. 


\section{References}

Ausubel, F. M., Brent, R., Kingston, R. E., Moore, D. D., Seidman, J. G., Smith, J. A. \& Struhl, K. (1987). Current Protocols in Molecular Biology. New York: Wiley.

Chern, L. L., Stackebrandt, E., Lee, S. F., Lee, F. L., Chen, J. K. \& Fu, H. M. (2004). Chitinibacter tainanensis gen. nov., sp. nov., a chitindegrading aerobe from soil in Taiwan. Int J Syst Evol Microbiol 54, 1387-1391.

Fitch, W. M. (1971). Toward defining the course of evolution: minimum change for a specific tree topology. Syst Zool 20, 406-416.

Groth, I., Schumann, P., Weiss, N., Martin, K. \& Rainey, F. A. (1996). Agrococcus jenensis gen. nov., sp. nov., a new genus of actinomycetes with diaminobutyric acid in the cell wall. Int J Syst Bacteriol 46, 234-239.

Kumar, S., Tamura, K. \& Nei, M. (2004). MEGA3: integrated software for molecular evolutionary genetics analysis and sequence alignment. Brief Bioinform 5, 150-163.

Kwon, S.-W., Kim, J.-S., Park, I.-C., Yoon, S.-H., Park, D.-H., Lim, C.-K. \& Go, S.-J. (2003). Pseudomonas koreensis sp. nov., Pseudomonas umsongensis sp. nov. and Pseudomonas jinjuensis sp. nov., novel species from farm soils in Korea. Int J Syst Evol Microbiol 53, 21-27.

Logan, N. A. (1989). Numerical taxonomy of violet-pigmented, gram-negative bacteria and description of Iodobacter fluviatile gen. nov., comb. nov. Int J Syst Bacteriol 39, 450-456.
Mesbah, M., Premachandran, U. \& Whitman, W. B. (1989). Precise measurement of the $\mathrm{G}+\mathrm{C}$ content of deoxyribonucleic acid by high-performance liquid chromatography. Int J Syst Bacteriol 39, 159-167.

Reasoner, D. J. \& Geldreich, E. E. (1985). A new medium for the enumeration and subculture of bacteria from potable water. Appl Environ Microbiol 49, 1-7.

Saitou, N. \& Nei, M. (1987). The neighbor-joining method: a new method for reconstructing phylogenetic trees. Mol Biol Evol 4, 406-425.

Smibert, R. M. \& Krieg, N. R. (1994). Phenotypic characterization. In Methods for General and Molecular Bacteriology, pp. 607-654. Edited by P. Gerhardt, R. G. E. Murray, W. A. Wood \& N. R. Krieg. Washington, DC: American Society for Microbiology.

Tanaka, K., Nakamura, K. \& Minaki, E. (1991). Fermentation of Scitramalate, citrate, mesaconate, and pyruvate by a gram-negative strictly anaerobic non-spore-former, Formivibrio citricus gen. nov. sp. nov. Arch Microbiol 155, 491-495.

Thompson, J. D., Higgins, D. G. \& Gibson, T. J. (1994). CLUSTAL W: improving the sensitivity of progressive multiple sequence alignment through sequence weighting, position-specific gap penalties and weight matrix choice. Nucleic Acids Res 22, 4673-4680.

Yang, H.-C., Im, W.-T., An, D.-S., Park, W.-H., Kim, I. S. \& Lee, S.-T. (2005). Silvimonas terrae gen. nov., sp. nov., a novel chitin-degrading facultative anaerobe belonging to the 'Betaproteobacteria'. Int J Syst Evol Microbiol 55, 2329-2332. 